К.О. Надутий', В.М. Лехан ${ }^{2}$, О.К. Толстанов ${ }^{3}$

${ }^{1}$ Патронатна служба Верховної Ради України, Київ

${ }^{2}$ Державний заклад «Дніпропетровська медична академія МОз України», Дніпро

${ }^{3}$ Національна медична академія післядипломної освіти імені П.Л. Шупика, Київ

\title{
Методичні підходи до стандартизації оцінки діяльності закладів первинної медичної допомоги
}

Мета - розробка методичних підходів до стандартизації оцінки діяльності закладів первинної медичної допомоги. Методи дослідження: бібліосемантичний, концептуального моделювання, кваліметричний та статистичний. Результати. Розроблено триетапну методику стандартизації оцінки діяльності закладів первинної медичної допомоги, яка включає визначення переліку індикаторів, за допомогою яких повинна проводитись оцінка діяльності закладу; встановлення порядку оцінки й узагальнення її результатів з використанням кваліметричного підходу, детермінування процедури оцінки. Висновки. Розроблені методичні підходи дозволяють здійснювати на уніфікованій основі системний моніторинг ефективності діяльності закладів первинної медичної допомоги, виявляти типові та притаманні конкретним закладам проблемні зони та планувати їх усунення в національному, регіональному або місцевому масштабах із залученням всіх заінтересованих сторін (працівників закладів, органів управління, громадських та пацієнтських організацій). Запропонований методичний інструментарій доцільно використовувати при розробці бізнес-планів для надавачів первинної медичної допомоги.

Ключові слова: первинна медична допомога, стандартизація оцінки, кваліметричний підхід.

\section{Вступ}

На сучасному етапі розвитку систем охорони здоров'я в усіх країнах світу зміцнення первинної медико-санітарної допомоги (ПМСД) посідає провідне місце, що підтверджується низкою актуальних документів Організації об'єднаних націй (ОOH), Всесвітньої організації охорони здоров'я (ВООЗ) та інших міжнародних організацій. ВООЗ визнає ПМСД найважливішим елементом національних систем охорони здоров'я (WHO, 2008). До такого самого висновку приходить і організація економічного співробітництва і розвитку (Organisation for Economic Co-operation and Development - OECD), яка в своїй доповіді «Health at a glance» 2015 р. акцентує увагу на тому, що досягнення високого рівня надання первинної медичної допомоги (ПМД) є першочерговим завданням практично для кожної країни, яка входить до складу OECD. На ще вищий рівень піднесено значення ПМД у резолюції Генеральної Асамблеї ООН A/RES/67/81. «Здоров'я населення світу і зовнішня політика", де констатується, що «ефективне і стійке у фінансовому плані впровадження загального медичного забезпечення ґрунтується на надійних і ефективних системах охорони здоров'я, які забезпечують всеосяжне первинне медико-санітарне обслуговування...», включаючи “широкомасштабні державні заходи в галузі охорони здоров'я» (General Assembly, 2012). У документах до Глобальної конференції з первинної медико-санітарної допомоги, що проводилася в ознаменування 40-ї річниці Алма-Атинської декларації, знову відзначаються і підтверджуються закладені в цій декларації основоположні принципи, а також пропонується відновити політичну прихильність концепції ПМСД, ставлячи ї̈ на центральне місце в роботі щодо забезпечення загального охоплення послугами охорони здоров'я і досягнення цілей в галузі сталого розвитку (WHO, 2018).

Нова хвиля інтересу до ПМД спричинена виникненням останнім часом серйозних викликів, що потребують системних відповідей, зумовлених значними змінами демографічних, епідеміологічних, політичних, економічних, соціокультурних і науково-технічних факторів. Основні з таких викликів:

- наростаючий процес старіння населення;

- епідеміологічні зрушення - від переважання інфекцій і перинатальних та акушерських причин захворюваності та смертності до неінфекційних захворювань;
- погіршення соціальних детермінант здоров'я серед малозабезпечених груп населення та поглиблення нерівності в показниках здоров'я;

- зміна соціокультурних очікувань, коли громадяни розраховують на отримання всебічних послуг, що відповідають ї конкретним потребам;

- глобальна економічна криза, яка призвела, починаючи з 2008 р., до зниження темпів економічного зростання та обмеження бюджетних можливостей для інвестування в системи охорони здоров'я (WHO, 2018).

Усі ці проблеми притаманні й українській системі пМД. Додатково ускладнюють ситуацію турбулентність політики стосовно розвитку системи охорони здоров'я в цілому та відсутність чіткої стратегії перетворень первинної ланки, незавершеність трансформації системи на засади загальної практики - сімейної медицини, недосконалість її матеріально-технічного, інформаційного, фінансово-економічного та кадрового забезпечення.

3 огляду на вищенаведене вирішення проблеми керованого розвитку та зміцнення національної системи ПМСД в Україні $€$ надактуальним завданням політики у сфері охорони здоров'я, оскільки доведено, що системи охорони здоров'я, які спираються на сильну ПМСД, більш стійкі, ефективніші та справедливіші.

Основним компонентом ПМД є практики ПМД. Належна практика ПМД - це відповідність будь-якого надавача/закладу ПМД існуючим вимогам щодо доступності, якості, безпеки медичного обслуговування та чутливості до потреб пацієнтів і медичного персоналу, що дозволяє досягти максимальної, з урахуванням наявного фінансового забезпечення, результативності та ефективності його діяльності.

Важливим інструментом для формування сильної системи ПМСД в цілому і належної практики ПМД зокрема є моніторинг та обмін надійними даними щодо ії ефективності. На необхідності проведення моніторингу критично важливих показників ПМСД наполягає Нове партнерство у складі Фонду Білла і Мелінди Гейтс, Групи Світового банку та ВОO3 (WHO, 2015), створене для підвищення ефективності ПМсД. Зокрема Б. Гейтс, співзасновник партнерства, у своєму виступі зазначив: «Час поставитися серйозно до простежування і вимірювання ефективності первинної медико-санітарної допомоги, з тим щоб країни мали дані, необ- 
хідні для них з метою ефективного використання ресурсів для поліпшення здоров'я своїх громадян... ». Проведення такого моніторингу потребує уніфікованого методичного підходу, використання якого дозволить як оцінювати ефективність ПМД в цілому та її окремих закладів, так і здійснювати стратегічне, тактичне й оперативне планування її розвитку.

Мета - розроблення методичних підходів до стандартизації/ уніфікації оцінки діяльності закладів ПМД.

\section{Об'єкт і методи дослідження}

Об’єктом дослідження є система ПМД. У роботі використано методи: бібліосемантичний, концептуального моделювання, кваліметричний і статистичний.

\section{Результати та їх обговорення}

Розроблення методичних підходів до стандартизованої оцінки діяльності закладів ПМД здійснювали в три етапи:

1. Визначення переліку індикаторів, за допомогою яких повинна проводитись оцінка діяльності закладу ПМД

2. Встановлення порядку оцінки закладу ПМД і узагальнення результатів її діяльності.

3. Детермінування процедури оцінки.

\section{Характеристика I етапу}

Формування переліку індикаторів здійснювали відповідно до міжнародно погоджених принципів:

- актуальність для вироблення політики - використовувані індикатори повинні відображати поставлені перед системою цілі;

- відповідність циклу прийняття рішень - застосування індикаторів з тією самою періодичністю, з якою приймають рішення;

- неможливість легкого маніпулювання чи спотворення під дією сторонніх чинників - мінімізація кількості індикаторів, які можуть бути надмірно чутливими до зовнішніх або екзогенних факторів, та індикаторів, якими легко маніпулювати (наприклад якщо практикується внутрішня звітність або якщо система стимулів створює заінтересованість у завищенні/заниженні дійсних результатів) (Капица Л.М., 2008).

Попередній перелік індикаторів розроблений групою із 6 експертів в галузях загальної практики - сімейної медицини та організації охорони здоров'я, із врахуванням аналізу цілей, завдань та професійних компетенцій ПМД. Індикатори розробляли таким чином, щоб якомога повніше відобразити актуальний стан ПМД в Україні. Остаточний варіант сформовано після перевірки в локальному організаційному експерименті на базі п'яти закладів ПМД із внесенням відповідних коректив. Зазначимо, що з розвитком ПМД і визначенням нових цілей і пріоритетів індикатори можуть бути модифіковані чи змінені відповідно до нових потреб, можливостей або проблем, які виникатимуть у процесі розвитку ПмД та/чи системи громадського здоров'я.

Комплекс індикаторів згідно із сучасними підходами, рекомендованими в тому числі Агенцією з дослідження якості медичної допомоги США (Agency for Healthcare Research and Quality AHRQ) 2011 р., включав характеристики ресурсів закладу ПМД (індикатори структури), сукупності взаємопов'язаних дій, які перетворюють входи у виходи для отримання заздалегідь визначених продуктів або послуг, маючих цінність для споживача (індикатори процесу) та показників, що відображають вплив системи ПМД на здоров'я населення (індикатори результату).

Весь комплекс запропонованих індикаторів розбитий на 5 груп з використанням як основних класифікаційних ознак провідних характеристик якості медичного обслуговування:

І. Індикатори доступності надання ПМД. Група критеріїв, які показують, наскільки доступною (легкою для отримання) є медична допомога для населення (перелік, вид та призначення індикаторів представлені в табл. 1).

II. Індикатори якості надання ПМД. Група критеріїв, які показують, наскільки якісні медичні послуги може отримати пацієнт у цьому закладі (табл. 2).

III. Індикатори ефективності/результативності надання ПМД. Група критеріїв, які показують, наскільки ефективною та результативною є робота цього закладу ПМД (табл. 3).

IV. Індикатори безпеки надання ПМД. Група критеріїв, які показують, наскільки безпечним є отримання медичної допомоги в закладі ПМД (табл. 4).

V. Індикатори, які характеризують чутливість, - зручність і комфортність для пацієнтів перебування у закладі ПМД та виконання службових обов'язків для медичного персоналу (табл. 5).

На цьому самому етапі визначають джерела отримання інформації та методику розрахунку кожного з індикаторів. Зазначимо, що деякі індикатори (позначені в табл. 2 і 3 «*») можуть бути виключно чи ефективніше отримані за наявності електронної інформаційної системи. Проте їх враховують при проведенні оцінки закладу/підрозділу як певний спосіб мотивації до прискорення інформатизації в системі ПМСД та формування її дизайну.

Таблиця 1. Перелік, вид та призначення індикаторів доступності ПМД

\begin{tabular}{|c|c|c|}
\hline \multicolumn{3}{|c|}{ Індикатори } \\
\hline Назва & $\begin{array}{c}\text { Тип } \\
\text { (структура - c) }\end{array}$ & Призначення \\
\hline Рівень фізичної доступності закладу & $\mathrm{C}$ & Вказує, наскільки легко пацієнтам добратися до закладу ПМД \\
\hline $\begin{array}{l}\text { Рівень фізичної доступності лікаря, що надає ПМД (навантаження } \\
\text { на лікаря)* }\end{array}$ & C & $\begin{array}{l}\text { Вказує, наскільки легко пацієнту потрапити на прийом до лікаря, } \\
\text { враховуючи його навантаження }\end{array}$ \\
\hline $\begin{array}{l}\text { Рівень раціональності використання робочого часу лікаря та доступ- } \\
\text { ності медичної допомоги вдома }\end{array}$ & C & $\begin{array}{l}\text { Вказує, наскільки організація ПМД сприяє раціоналізації використання } \\
\text { робочого часу лікаря без необґрунтованих обмежень доступності } \\
\text { допомоги вдома }\end{array}$ \\
\hline $\begin{array}{l}\text { Рівень фізичної доступності медсестри середнього фахівця ПМД } \\
\text { (сестра медична загальної практики - сімейної медицини, акушерка, } \\
\text { фельдшер тощо), навантаження на медичну сестру^ }\end{array}$ & c & $\begin{array}{l}\text { Вказує, наскільки легко пацієнту потрапити на прийом до медичної } \\
\text { сестри, враховуючи її навантаження }\end{array}$ \\
\hline Рівень ефективності використання професійного потенціалу медсестер & C & $\begin{array}{l}\text { Вказує, наскільки легко пацієнту отримати допомогу медичної сестри } \\
\text { за відсутності потреби пацієнта в компетенції лікаря }\end{array}$ \\
\hline $\begin{array}{l}\text { Рівень фізичної доступності медичного персоналу протягом дня } \\
\text { та тижня для різних категорій пацієнтів }\end{array}$ & C & Вказує, наскільки зручним для пацієнтів є графік прийому лікарів \\
\hline Рівень оснащеності автотранспортом & c & $\begin{array}{l}\text { Визначає, наскільки своєчасно можуть бути надані медичні послуги } \\
\text { на дому }\end{array}$ \\
\hline Рівень фізичної доступності лабораторних досліджень & C & $\begin{array}{l}\text { Вказує, наскільки легко пацієнту дістатися до місця проведення } \\
\text { необхідних досліджень }\end{array}$ \\
\hline Рівень економічної доступності лабораторних досліджень & c & $\begin{array}{l}\text { Вказує, наскільки фінансово доступним є проведення необхідних } \\
\text { досліджень для пацієнта }\end{array}$ \\
\hline Наявність ліків для надання допомоги у невідкладних станах & C & $\begin{array}{l}\text { Показує готовність закладу надати невідкладну допомогу пацієнту } \\
\text { при виникненні такої необхідності }\end{array}$ \\
\hline $\begin{array}{l}\text { Рівень фізичної доступності місць продажу ліків та виробів медичного } \\
\text { призначення }\end{array}$ & C & $\begin{array}{l}\text { Вказує, наскільки зручно пацієнту отримати/придбати медичні засоби } \\
\text { за призначенням лікаря }\end{array}$ \\
\hline
\end{tabular}

*0тримання індикатора можна забезпечити ефективніше при інформатизації закладу. 
Таблиця 2. Перелік, вид та призначення індикаторів якості ПмД

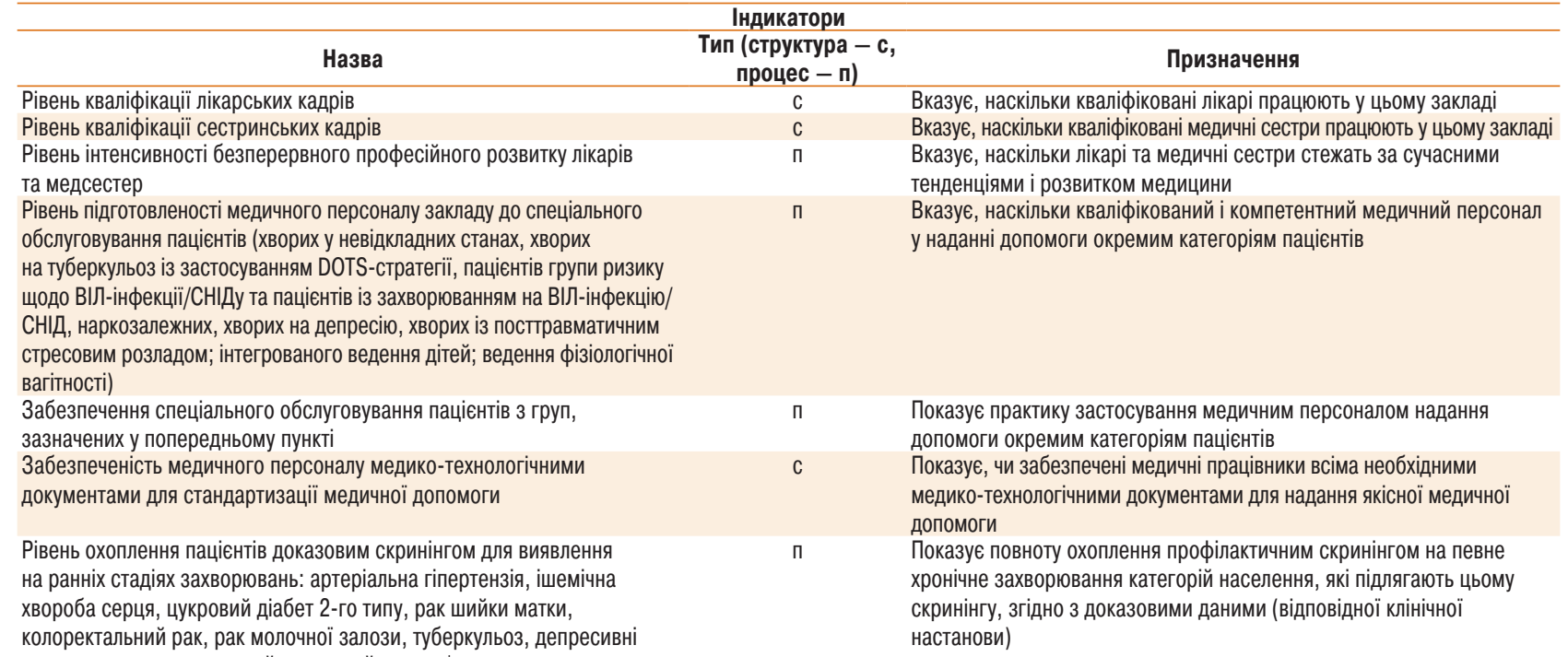

розлади, посттравматичний стресовий розлад ${ }^{*}$

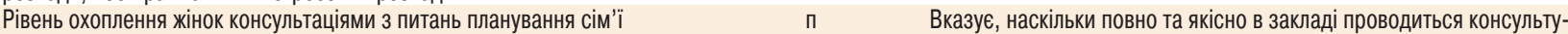

Рівень охоплення підлітків консультуванням з питань збереження репровання 3 питань планування сім'ї дуктивного здоров'я (запобігання небажаній вагітності, профілактики

п В Вказує, наскільки якісно в закладі проводиться консультування підліткового населення щодо збереження репродуктивного здоров'я

захворювань, що передаються статевим шляхом)

Рівень вторинної профілактики (контрольованого лікування) найпоширеніших хронічних неінфекційних захворювань (артеріальна гіпертензія, ішемічна хвороба серця, цукровий діабет 2-го типу, хронічне

обструктивне захворювання легень, бронхіальна астма) ${ }^{\star *}$

Рівень економічного стимулювання якості

Вказує на «управління випадками» найпоширеніших захворювань (виявлення, призначення лікування, забезпечення доступними ліками, контроль ефективності, корекція призначень)

Стан запровадження в закладі системи менеджменту якості

Вказує, наскільки медичний персонал економічно мотивований до підвищення якості та результативності медичної допомоги Вказує, чи запроваджена в закладі система менеджменту якості

Тут і в табл. 3: *для отримання індикатора необхідна інформатизація закладу; *夫отримання індикатора можна забезпечити ефективніше при інформатизації закладу.

Таблиця 3. Перелік, вид та призначення індикаторів ефективності ПМД

\begin{tabular}{|c|c|c|}
\hline \multicolumn{3}{|c|}{ Індикатори } \\
\hline Назва & Тип (результат - p) & Призначення \\
\hline $\begin{array}{l}\text { Рівень імунізації від керованих інфекцій (кір, краснуха, паротит; } \\
\text { туберкульоз; дифтерія, коклюш, правець; гемофільна інфекція; } \\
\text { поліомієліт, вірусний гепатит В) }\end{array}$ & $p$ & $\begin{array}{l}\text { Вказує, наскільки ефективною є превентивна діяльність у запобіганні } \\
\text { керованим інфекційним захворюванням }\end{array}$ \\
\hline $\begin{array}{l}\text { Частота дефектів (задавнених випадків) у виявленні окремих видів } \\
\text { захворювань у ранніх стадіях (туберкуль03, рак шийки матки, } \\
\text { колоректальний рак, рак молочної залози, рак шкіри) }\end{array}$ & p & $\begin{array}{l}\text { Вказує, наскільки ефективно в закладі ПМД діють скринінгові програми } \\
\text { для раннього виявлення певних захворювань }\end{array}$ \\
\hline $\begin{array}{l}\text { Рівень запобігання виникненню невідкладних станів, що потребують } \\
\text { екстреної медичної допомоги (частота викликів екстреної медичної } \\
\text { допомоги на } 1000 \text { прикріпленого населення по закладу ПМд)* }\end{array}$ & p & $\begin{array}{l}\text { Вказує, наскільки ефективно в закладі профілактується виникнення } \\
\text { гострих та невідкладних станів }\end{array}$ \\
\hline $\begin{array}{l}\text { Рівень запобігання формуванню захворювань і станів, що потребують } \\
\text { стаціонарного лікування (частота госпіталізації на } 100 \text { осіб прикріпле- } \\
\text { ного населення по закладу ПМД)* }\end{array}$ & $\mathrm{p}$ & $\begin{array}{l}\text { Вказує, наскільки ефективно в закладі профілактується виникнення } \\
\text { станів, що потребують стаціонарного лікування }\end{array}$ \\
\hline $\begin{array}{l}\text { Рівень адекватності місця надання медичної допомоги (\% закінчених } \\
\text { на рівні ПМД випадків обслуговування із загальної кількості звертань } \\
\text { до закладу ПМД)夫夫 }\end{array}$ & $\mathrm{p}$ & $\begin{array}{l}\text { Показує рівень ефективності надання медичної допомоги на первинній } \\
\text { ланці }\end{array}$ \\
\hline Рівень задоволеності пацієнтів отриманою ПМД & $\mathrm{p}$ & $\begin{array}{l}\text { Вказує, наскільки пацієнти, що обслуговуються в закладі ПМД, } \\
\text { задоволені наданою медичною допомогою }\end{array}$ \\
\hline
\end{tabular}

\section{Характеристика II етапу}

Оскільки для оцінки різних аспектів діяльності закладів ПМсД використовують як якісні, так і кількісні індикатори, для її уніфікації застосовували кваліметричний підхід - методологію комплексного кількісного оцінювання якості об'єктів будь-якої природи (Azgaldov G.G., Kostin A.V., 2011). Кількісні індикатори, розраховані в частках одиниці, процентах, проміле, градуюють за 4-мірною шкалою: достатній/високий, середній, недостатній, низький рівні, які потім конвертують в бальну оцінку в межах 1-0. Достатній рівень показника відповідає міжнародно визнаним в охороні здоров'я критеріям (наприклад достатнім вважають рівень охоплення вакцинацією 95\%), інші градації визначають експерти з урахуванням існуючих в національній охороні здоров'я тенденцій. Якісні показники градуюють за 2-мірною шкалою (наявний - відсутній, так - ні) і також конвертують у бали 1 і 0.

Оскільки внесок різних індикаторів у загальну оцінку діяльності роботи закладу неоднаковий, слід враховувати їх відносну важ- ливість, для чого кожному індикатору експертно присвоюють відповідні вагові коефіцієнти (зазвичай 3-10). Для отримання кінцевого значення індикатора бальну оцінку перемножують на ваговий коефіцієнт. Далі по кожній групі індикаторів (доступність, якість, результативність, безпека, чутливість) визначають із врахуванням вагових коефіцієнтів максимальні та фактично набрані бали, їх суму та частку відповідності. На рисунку представлено структуру оцінки по групах індикаторів у максимальній кількості балів.

\section{Характеристика III етапу}

Процедура оцінки відбувається у 5 етапів:

1. Самооцінка. На цьому етапі працівники закладу заносять усі необхідні дані й проводять експертну оцінку закладу самостійно.

2. Зовнішній аудит, який проводять комісії у складі представників різних амбулаторій та керівних структур. Ці комісії здійснюють перевірку достовірності вхідних даних та експертну оцінку якісних показників. 
Таблиця 4. Перелік, вид та призначення індикаторів безпеки ПмД

\begin{tabular}{|c|c|c|}
\hline \multicolumn{3}{|c|}{ Індикатори } \\
\hline Назва & $\begin{array}{c}\text { Тип } \\
\text { (структура - c) }\end{array}$ & Призначення \\
\hline $\begin{array}{l}\text { Рівень організації дотримання санітарно-епідеміологічних вимог } \\
\text { у приміщенях закладу }\end{array}$ & $\mathrm{C}$ & Визначає, чи правильно проводиться прибирання приміщень \\
\hline Рівень гарантій безпеки повітря у приміщеннях закладу & C & Визначає, чи правильно проводиться обробка повітря \\
\hline $\begin{array}{l}\text { Рівень використання одноразового інструментарію при обслуговуванні } \\
\text { пацієнтів }\end{array}$ & C & $\begin{array}{l}\text { Визначає, наскільки високий рівень запобігання інфікуванню хворих } \\
\text { ятрогенним шляхом }\end{array}$ \\
\hline Рівень організації обслуговування пацієнтів із лихоманкою & C & $\begin{array}{l}\text { Визначає, наскільки високий рівень запобігання передачі інфекційної } \\
\text { патології між хворими }\end{array}$ \\
\hline Рівень організації прийому дітей молодших вікових категорій & C & $\begin{array}{l}\text { Визначає рівень безпеки при обслуговуванні дітей молодших вікових } \\
\text { категорій }\end{array}$ \\
\hline
\end{tabular}

Таблиця 5. Перелік, вид та призначення індикаторів чутливості закладів ПМД

\begin{tabular}{|c|c|c|}
\hline \multicolumn{3}{|c|}{ Індикатори } \\
\hline Назва & $\begin{array}{l}\text { Тип } \\
\text { (структура - с, } \\
\text { процес - п) }\end{array}$ & Призначення \\
\hline $\begin{array}{l}\text { Рівень доступу у приміщення закладу для візкових інвалідів і матерів } \\
\text { з немовлятами (у візках) }\end{array}$ & c & $\begin{array}{l}\text { Показує зручність доступу до закладу ПМД людей з особливими } \\
\text { потребами }\end{array}$ \\
\hline Рівень доступності інформації щодо роботи закладу & c & $\begin{array}{l}\text { Визначає, з яких джерел пацієнт може отримати інформацію щодо } \\
\text { роботи закладу ПМД }\end{array}$ \\
\hline Рівень організації запису на прийом та ведення черги & $c$ & $\begin{array}{l}\text { Визначає наявність можливостей дистанційного запису пацієнтів } \\
\text { на прийом до лікаря та/чи медичної сестри і ефективність їхнього } \\
\text { використання }\end{array}$ \\
\hline $\begin{array}{l}\text { Рівень зручності доступу до всіх приміщень закладу, де ведеться } \\
\text { обслуговування пацієнтів «не по східцях» (з огляду на обслуговування } \\
\text { людей із проблемами опорно-рухового апарату, візкових інвалідів } \\
\text { і матерів з немовлятами) }\end{array}$ & C & $\begin{array}{l}\text { Показує зручність доступу до закладу ПМД людей з обмеженими } \\
\text { можливостями }\end{array}$ \\
\hline Рівень доступності туалетів для всіх категорій пацієнтів & c & $\begin{array}{l}\text { Визначає доступність туалетів для відвідувачів (у тому числі осіб } \\
\text { з обмеженими можливостями) }\end{array}$ \\
\hline Рівень доступності місць для сповивання немовлят & C & Визначає рівень уваги до потреб матерів із немовлятами \\
\hline Наявність виділеної зони для дітей & C & Визначає рівень уваги до потреб матерів із дітьми \\
\hline $\begin{array}{l}\text { Наявність інструменту громадського спостереження нагляду } \\
\text { за роботою закладу }\end{array}$ & c & Вказує, чи здійснюється громадський контроль за роботою закладу \\
\hline Рівень уваги до думки пацієнтів & $\Pi$ & Вказує, чи вивчається та враховується думка пацієнтів \\
\hline Рівень уваги до думки надавачів ПМД & $\Pi$ & Вказує, чи вивчається та враховується думка медичного персоналу \\
\hline
\end{tabular}

3. Громадський аудит, що проводять представники професійних асоціацій (Українська асоціація сімейної медицини) або спеціалізованих консалтингових/аудиторських організацій із залученням представників професійних асоціації. Здійснюється перевірка достовірності вхідних даних та експертна оцінка якісних показників. Перевірку доцільно проводити у лідерів рейтингу і вибірково серед усіх закладів.

4. Виявлення загальних і поширених проблем та обговорення результатів. На цьому етапі робиться загальний висновок щодо відповідності закладу критеріям належної практики та виявлення типових проблем і невідповідностей.

5. Планування. 3 використанням цього інструменту органи державної влади, корпоративні об'єднання власників закладів охорони здоров'я, корпоративні об'єднання надавачів ПМСД, професійні асоціації, консалтингові організації можуть виявляти заклади, в яких типові проблеми, притаманні іншим закладам, вирішені, і на основі їхнього досвіду формувати кейси вдалих рішень. Ці кейси пропонуються закладам із такими проблемами

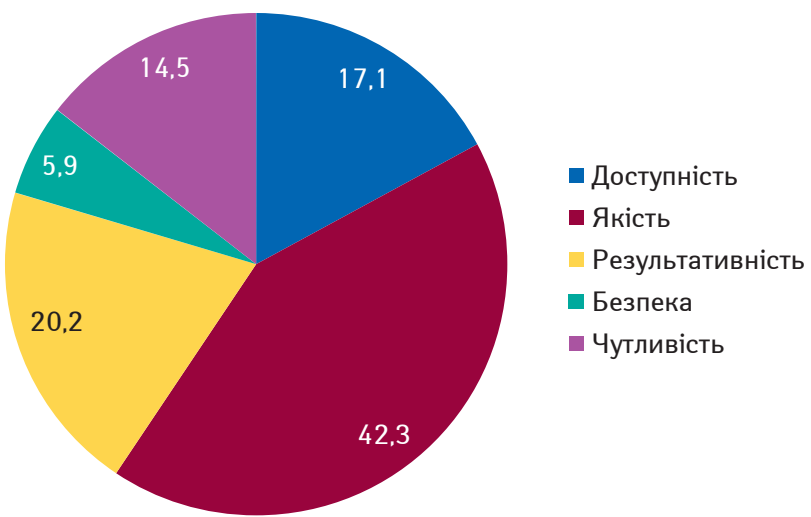

Рисунок. Структура максимальної оцінки діяльності закладу за групами індикаторів (\%) для допомоги щодо їх вирішення. Планування може здійснюватися на підставі самооцінки (процедурний етап I) або самооцінки і зовнішнього аудиту (процедурні етапи I і II), проте керівникам закладів та їх власникам варто враховувати, що об'єктивність і коректність висновків громадського аудиту із залученням професійних асоціацій та спеціалізованих організацій є значно вищими.

\section{Висновки}

Розроблені методичні підходи дозволяють здійснювати на уніфікованій основі системний моніторинг ефективності діяльності закладів ПМСД, виявляти типові та притаманні конкретним закладам проблемні зони і планувати їх усунення та розвиток ПМСД в національному, регіональному або місцевому масштабах із залученням всіх заінтересованих сторін (працівників закладів, органів управління, громадських та пацієнтських організацій).

Запропонований методичний інструментарій доцільно використовувати при розробці бізнес-планів для надавачів ПМСД.

\section{Список використаної літератури}

Капица Л.М. (2008) Индикаторы мирового развития. МГИМО-Университет, Москва, $351 \mathrm{c}$

AHRQ (2011) Types of Health Care Quality Measures. Agency for Healthcare Research and Quality (https://www.ahrq.gov/talkingquality/measures/types.html).

Azgaldov G.G., Kostin A.V. (2011) Applied qualimetry: its origins, errors and misconceptions. Benchmarking: Intern. J., 18(3): 428-444.

General Assembly (2012) Resolution adopted by the General Assembly on 12 December 2012 (https://undocs.org/A/RES/67/81).

OECD (2015) Health at a Glance 2015 OECD indicators (http://apps.who.int/ medicinedocs/documents/s22177en/s22177en.pdf).

WHO (2008) The world health report 2008: primary health care now more than ever (http://www.who.int/iris/handle/10665/43949).

WHO (2015) New partnership to help countries close gaps in primary health care (https://www.who.int/mediacentre/news/releases/2015/partnership-primaryhealth-care/en/).

WHO (2018) From Alma-Ata to Astana:Primary health care - reflecting on the past, transforming for the futurelnterim Report from the WHO European Region 
(https://www.who.int/docs/default-source/primary-health-care-conference/phcregional-report-europe.pdf?sfvrsn=cf2badeb 2).

\section{Методические подходы к стандартизации оценки деятельности учреждений первичной медицинской помощи \\ К.А. Надутый, В.М. Лехан, А.К. Толстанов}

Резюме. Цель - разработка методических подходов к стандарти зации оценки деятельности учреждений первичной медицинской помощи. Методы исследования: библиосемантический, концептуального моделирования, квалиметрический и статистический. Результаты. Разработана трехэтапная методика стандартизации оценки деятельности учреждений первичной медицинской помощи, включающая определение перечня индикаторов, с помощью кото рых должна проводиться оценка деятельности учреждения; установление порядка оценки и обобщения ее результатов с использованием квалиметрического подхода; детерминирование процедуры оценки. Выводы. Разработанные методические подходь позволяют осуществлять на унифицированной основе системный мониторинг эффективности деятельности учреждений первичной медицинской помощи, выявлять типичные и присущие конкретным учреждениям проблемные зоны и планировать их устранение в национальном, региональном или местном масштабах с привлечени ем всех заинтересованных сторон (работников учреждений, органов управления, общественных и пациентских организаций). Предложенный методический инструмент целесообразно использовать при разработке бизнес-планов для поставщиков первичной меди цинской помощи.

Ключевые слова: первичная медицинская помощь, стандартизация оценки, квалиметрический подход.

\section{Methodical approaches to standardizing the assessment of primary health care units \\ K. O. Nadutiy, V.M. Lekhan, O.K. Tolstanov}

Summary. The goal is to develop methodological approaches to standardizing the assessment of primary health care units. Research methods: the bibliosemantic, conceptual modeling, qualimetric and statistical. Results. A three-stage standardization methodology for evaluating the activities of primary health care units has been developed: defining a list of indicators for conducting an assessment; establishing the procedure for assessing and summarizing its results using a qualimetric approach; the determination of the evaluation procedure. Conclusions. The developed methodological approaches allow for a systematic monitoring of the performance of primary health care units in a unified manner, identify typical and specific problem areas and plan for their elimination at the national, regional or local scale with the involvement of all stakeholders (medical personal, employees of governing bodies, public and patient organizations). The proposed methodological tools should be used when developing business plans for primary care providers.

Key words: primary health care, assessment standardization, qualimetric approach.

\section{Адреса для листування:}

\section{Валерія Микитівна Лехан}

49000, Дніпро, вул. Володимира Вернадського, 9

Державний заклад «Дніпропетровська медична академія М03 України» E-mail:v.n.lexan@gmail.com

Одержано 23.05.2019 